\title{
Blocking of Type 1 Angiotensin II Receptor Inhibits T-lymphocyte Activation and IL-2 Production
}

\author{
SUPANNIKAR TAWINWUNG, NALINRAT PETPIROON and PITHI CHANVORACHOTE \\ Department of Pharmacology and Physiology, Faculty of Pharmaceutical Sciences, \\ Cell-based Drug and Health Products Development Recearch Unit, Chulalongkorn University, Bangkok, Thailand
}

\begin{abstract}
Background/Aim: Novel information on the role of endogenous compounds in regulating physiological and pathological process are of interest, as it may lead to the development of better strategies for disease management. The role of angiotensin II and the signaling of type 1 angiotensin II receptor (AGTIR) in T-lymphocyte activation and interleukin-2 (IL-2) production are largely unknown. Materials and Methods: Jurkat T-cells were treated with AGT1R inhibitor candesartan and stimulated with phorbol myristate acetate (PMA) and ionomycin. T-Cell activation, associated cytokine production and levels of signaling proteins were evaluated by flow cytometry and western blot analysis. Results: Candesartan significantly suppressed PMA and ionomycin-induced CD25 expression and IL-2 production. Regarding the molecular mechanism involved, we showed that such suppressive effects of blocking of AGT1R by candesartan resulted in the significant inhibition of ERK activation in PMA-stimulated Jurkat T-cells. The effect of ERK inhibition on T-cell activation was further confirmed. Treatment with FR180204, a specific ERK inhibitor, reduced $T$-cell activation and $I L-2$ secretion. Conclusion: AGT1R signaling is essential for T-cell activation and IL-2 production, and the inhibition of this pathway suppressed T-cell activation via an ERK-dependent mechanism.
\end{abstract}

The most fundamental trait of endogenous mediators is their activity in regulation of cell, tissue and organ functions. The dysregulation of, or altered response to such mediators may lead to the pathogenesis of diseases. The novel actions of

This article is freely accessible online.

Correspondence to: Dr. Pithi Chanvorachote, Department of Pharmacology and Physiology, Faculty of Pharmaceutical Sciences, and Cell-based Drug and Health Product Development Research Unit, Chulalongkorn University, Bangkok, Thailand. Tel: +662 2188285, Fax: +662 2188340, e-mail: pithi_chan@yahoo.com

Key Words: Angiotensin, T-lymphocyte, IL-2, candesartan, ERK. known endogenous substances, including hormones, have been intensively unraveled and such information is of importance for the better understanding of biology, and physiological and pathological processes. Regarding the cardiovascular system, the renin-angiotensin system (RAS) is essential for regulation of blood pressure and fluid homeostasis $(1,2)$. The primary effector molecule, angiotensin II, acts through type 1 and type 2 angiotensin II receptors (AGT1R and AGT2R).

There is evidence indicating that angiotensin II may play a role in regulating the immune system (3-6). For example, angiotensin II was shown to stimulate production and secretion of several pro-inflammatory cytokines involved in the pathogenesis of atherosclerosis (7) and chronic kidney injury (5). In addition, study in an in vivo model of immunemediated renal injury revealed that in mice the deletion of Agt1r reduced glomerular expression of monocyte chemoattractant protein-1 and ameliorated proteinuria as well as glomerular tissue damage (8). More importantly, a classic angiotensin receptor blocker has been proposed to reduce inflammation and modulate autoimmunity $(9,10)$.

As knowledge on the direct regulatory effect of angiotensin II in controlling immune cell functions and AGT1R signaling in immune cells remains limited, the present study aimed to provide more information regarding the role of angiotensin II and the function of AGT1R in the activation of T-lymphocytes (T-cells).

\section{Materials and Methods}

Materials and reagents. Jurkat T-cells, clone E6-1, were obtained from the American Type Culture Collection (Manassas, VA, USA). Roswell Park Memorial Institute (RPMI)-1640, fetal bovine serum (FBS), L-glutamine, and penicillin and streptomycin were purchased from Gibco/Life Technologies (Carlsbad, CA, USA). Selective AGT1R inhibitor candesartan, pretein kinase $\mathrm{C}$ activator phorbol 12-myristate 13-acetate (PMA), and calcium ionophore ionomycin calcium salt were purchased from Sigma Chemical (St. Louis, MO, USA). Cell proliferation reagent WST-1, and AKT inhibitor perifosine were also from Sigma Chemical. Lysis buffer and Complete Mini cocktail protease inhibitor were obtained from Roche Molecular Biochemicals (Indianapolis, IN, USA). BCA 
protein assay kit and SuperSignal West Pico Chemiluminescent substrate were from Pierce Biotechnology (Rockford, IL, USA). Primary antibodies for extracellular signal-regulated kinase (ERK), p-ERK, AKT, and p-AKT and peroxidase-conjugated secondary antibodies were from Cell Signaling Technology (Danvers, MA, USA). Fluorescein isothiocyanate (FITC)-conjugated monoclonal antibody for CD25 (CD25-4E3) was purchased from Thermo Scientific (Fremont, CA, USA). ERK inhibitor, FR180204, was from Merck Millipore (Darmstadt, Germany) and an enzyme-linked immunosorbent assay (ELISA) system was obtained from R\&D Systems (Minneapolis, MN, USA).

Cell culture. Jurkat T-cells were cultivated in Roswell Park Memorial Institute (RPMI)-1640 medium supplemented with $10 \%$ FBS, $2 \mathrm{mM} \mathrm{L}$-glutamine, and $100 \mathrm{U} / \mathrm{ml}$ penicillin and streptomycin. Cells were cultured in $24-w e l l$ plates and maintained in a $37^{\circ} \mathrm{C}$ humidified incubator with $5 \% \mathrm{CO}_{2}$.

Cytotoxicity assays. To evaluate cytotoxicity of candesartan, cells were seeded onto 96-well plates at a density of $5 \times 10^{5}$ cells/well and culture medium with different concentrations of candesartan was added to obtain final concentrations of $0-10 \mu \mathrm{M}$. After $24 \mathrm{~h}$, cell viability was measured using WST-1 reagent according to the manufacturer's protocol. The percentage of cell viability was calculated as the absorbance of treated cells relative to that of untreated cells.

Nuclear staining assay. Cells were seeded at a density of $1 \times 10^{5}$ cells per well onto a 96-well plate and treated with $0-1 \mu \mathrm{M}$ candesartan for $24 \mathrm{~h}$. Apoptotic and necrotic cell death was analyzed by subsequent incubation with $10 \mu \mathrm{g} / \mathrm{ml}$ of Hoechst 33342 and $5 \mu \mathrm{g} / \mathrm{ml}$ of propidium iodide (PI) for $30 \mathrm{~min}$ at $37^{\circ} \mathrm{C}$. Nuclear condensation and DNA fragmentation of apoptotic cells, as well as PI-positive necrotic cells, were visualized under a fluorescence microscope to observe nuclear morphology and PI-positive necrotic cells (Olympus IX51 with DP70 Digital camera system; Olympus, Central Valley, PA, USA).

Western blot analysis. Jurkat T-cells $\left(2 \times 10^{6}\right)$ were cultured in a $24-$ well plate. Cells were pre-treated with 0 or $1 \mu \mathrm{M}$ of candesartan for $15 \mathrm{~min}$ then stimulated with $25 \mathrm{ng} / \mathrm{ml}$ PMA plus $1 \mu \mathrm{M}$ ionomycin for 4 and $24 \mathrm{~h}$. After treatment, cells were harvested and solubilized for $1.5 \mathrm{~h}$ at $4^{\circ} \mathrm{C}$ in lysis buffer containing protease inhibitor mixture. Protein content in cell lysates was quantified using BCA protein assay kit. Equal amounts of denatured protein samples $(40 \mu \mathrm{g})$ were loaded onto $10 \%$ sodium dodecyl sulfate-polyacrylamide gel to undergo electrophoresis for separation of proteins by their molecular weight. The separated proteins were then transferred onto $0.45-\mu \mathrm{m}$ nitrocellulose membranes (Bio-Rad, Hercules, CA, USA). The membranes were blocked with $5 \%$ non-fat dry milk in $25 \mathrm{mMTris} \bullet \mathrm{HCl}$ (pH 7.5), $125 \mathrm{mM} \mathrm{NaCl}$, and $0.05 \%$ Tween 20 (TBST) for $2 \mathrm{~h}$ prior to incubation overnight at $4{ }^{\circ} \mathrm{C}$ with the primary antibodies specified above. The membranes were washed three times with TBST and incubated with appropriate horseradish peroxidase-labeled secondary antibodies for $2 \mathrm{~h}$ at room temperature. The immune complexes were detected by chemiluminescent substrate and quantified using Image J 1.51 j8 software (National Institutes of Health, Bethesda, MD, USA).

Flow cytometric analysis. Cells were pre-treated with either $1 \mu \mathrm{M}$ of candesartan, $10 \mu \mathrm{M}$ of FR180204, or $10 \mu \mathrm{M}$ of perifosine for $15 \mathrm{~min}$, followed by $25 \mathrm{ng} / \mathrm{ml}$ PMA plus $1 \mu \mathrm{M}$ ionomycin. Cells stimulated with PMA and ionomycin without pre-treatment served as control. After $24 \mathrm{~h}$, cells were washed with phosphate-buffered saline twice and incubated with FITC-conjugated monoclonal anti$\mathrm{CD} 25$ for $30 \mathrm{~min}$ at $4^{\circ} \mathrm{C}$. After staining, cells were washed twice with phosphate-buffered saline and the percentage of cells expressing CD25 was quantitated using a Guava easyCyte flow cytometer (Merck Millipore, Darmstadt, Germany).

Cytokine quantification. Cells were cultured at density of $2 \times 10^{6}$ cells $/ \mathrm{ml}$ in a 24-well plate. The cells were pre-treated with either $1 \mu \mathrm{M}$ of candesartan, $10 \mu \mathrm{M}$ of FR180204, or $10 \mu \mathrm{M}$ of perifosine for $15 \mathrm{~min}$ and stimulated with $25 \mathrm{ng} / \mathrm{ml}$ PMA plus $1 \mu \mathrm{M}$ ionomycin for $5 \mathrm{~h}$. Culture supernatants were collected and analyzed for IL-2 concentration using an ELISA assay, according to the manufacturer's protocols.

Statistical analysis. The data are presented as the mean \pm standard error (SEM) from three to five independent experiments. Statistical analysis was determined using two-way ANOVA and a post hoc test at a significance level of $p<0.05$.

\section{Results}

Effects of AGT1R blocker, candesartan on the viability of Jurkat T-cells. To study the role of AGT1R in regulation of T-lymphocyte activation, a selective AGRT1R inhibitor, candesartan, was used. Firstly, the cytotoxic effect of candesartan on the cells was determined. Jurkat T-cells were treated with serial dilution of candesartan ranging from 0 to $10 \mu \mathrm{M}$ for $24 \mathrm{~h}$. Cell viability was then measured using a WST-1 assay. Figure 1A shows that there was no significant difference in cell viability observed in response to the treatment of candesartan at $0-10 \mu \mathrm{M}$. This was confirmed by Hoechst 33342/PI staining assay showing that there were no apoptotic cells observed in cells treated with $1 \mu \mathrm{M}$ candesartan (Figure 1B).

Blocking of AGT1R by candesartan suppressed PMA/ionomycin-induced Jurkat T-cell activation. A previous study has shown that T-lymphocytes express AGT1R and produce local angiotensin II, which modulates T-cell functions (11) Therefore, we sought to determine the effects of AGT1R blockade, using candesartan, on the activation of T-cells. Jurkat T-cells were treated with the known T-cell activator, PMA $(25 \mathrm{ng} / \mathrm{ml})$ and ionomycin $(1 \mu \mathrm{M})$ in the presence or absence of candesartan $(1 \mu \mathrm{M})$ for $24 \mathrm{~h}$. The expression of T-cell activation marker CD25 was then analyzed by flow cytometry. As shown in Figure 2A, unstimulated Jurkat T-cells expressed a low level of CD25. The addition of candesartan significantly reduced CD25 expression by $32 \%$ in stimulated cells $(16.7 \% \pm 0.3$ in PMA/ionomycin vs. $11.2 \% \pm 0.5$ in PMA/ionomycin plus candesartan) (Figure 2B).

As we observed a significant decrease in T-cell activation marker in response to candesartan treatment, we sought to 


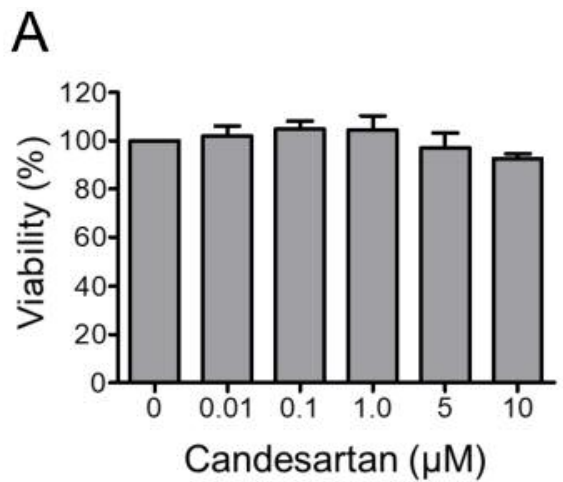

B

Figure 1. Effects of candesartan on the viability of Jurkat T-cells. A: Jurkat T-cells were treated with different concentrations of candesartan (0-10 $\mu M)$ for $24 \mathrm{~h}$. Cell viability was then determined using a WST-1 assay. Data are the mean \pm SEM (n=3). B: Hoechst33342/propidium iodide (PI) co-staining for nuclear morphology of the cells after treatment for the indicated time.

determine whether blocking AGT1R in Jurkat T-cells also inhibited their cytokine production. Jurkat T-cells were pretreated with candesartan and stimulated with PMA and ionomycin for $5 \mathrm{~h}$. Culture supernatant was then collected and analyzed for IL-2 concentration using ELISA. Pharmacologically blocking AGT1R was found to significantly suppress IL-2 production in activated T-cells (Figure 2C).

Candesartan inhibits T-cell activation through ERK suppression. Having shown that treatment with candesartan inhibited Jurkat T-cell activation and IL-2 production, we therefore investigated the possible mechanism by which inhibition of AGT1R could affect T-cell activation. Expression of ERK and AKT proteins, actors in known cellular pathways regulating $\mathrm{T}$-cell activation, was then determined by western blot analysis in PMA/ionomycinactivated cells treated with candesartan. As shown in Figure $3 \mathrm{~A}$, stimulation of the cells with PMA and ionomycin markedly induced ERK phosphorylation in Jurkat T-cells; however, pre-treatment with candesartan significantly attenuated this activation (p-ERK(1/2)) (Figure 3B). We observed that AKT activation was not altered in this experiment, suggesting that the AKT pathway was not affected by AGT1R blockade.

In order to confirm the role of ERK activation in T-cell activation and IL-2 secretion, Jurkat T-cells were pre-treated with the known ERK inhibitor FR18024 prior to PMA/ionomycin stimulation. The inhibition of ERK phosphorylation in this way significantly suppressed CD25 expression (Figure 4A) and IL-2 production (Figure 4B) in Jurkat T-cells, confirming our finding above. Moreover, treatment of the cells with the AKT inhibitor perifosine, did not alter T-cell activation induced by PMA and ionomycin stimulation. These results confirmed that the blocking of AGT1R attenuated T-cell activation via suppression of an ERK-related mechanism.

\section{Discussion}

Although since long known for its role in regulating hemodynamic homeostasis and water balance (2), novel biological and physiological functions of angiotensin II have been continuously discovered. For instance, angiotensin II was recently shown to have a function in enhancing cancer stem cell-like phenotypes in lung cancer cells (12). Exposure of lung cancer cells to angiotensin II at non-toxic concentrations induced key features of cancer stem cells, including their ability to grow as 3D tumor spheroids and under anchorageindependent conditions, together with the dramatic increase of emission of cancer stem cell markers (12). Angiotensin II was also found to affect cell proliferation (13-15), as well as the production and secretion pattern of pro-inflammatory cytokines (16-18). Such information leads to the possibility that angiotensin II may play a role in controlling cell signaling in inflammation and immune-mediated diseases.

T-Lymphocytes express AGT1R and other RAS components and locally produced angiotensin II has been shown to regulate immune cells $(19,20)$. Angiotensin II infusion of immunodeficient mice lacking T-and Blymphocytes reduced hypertension and vascular injury, while adoptive transfer of T-cells reversed these effects (21), suggesting the role of AGT1R signaling in the development of vascular diseases independent of hemodynamic function. Furthermore, in autoimmune disease models, including multiple sclerosis, and rheumatoid arthritis, infusion of angiotensin II led to severe disease while treatment with RAS inhibitor ameliorated the severity of the diseases (10, 22 , 23), suggesting crucial roles of angiotensin II as an proinflammatory mediator and immune regulator. However, how angiotensin II and AGT1R are involved in regulating Tcell function is still not clear.

Here we reported the role of AGT1R in the activation of Jurkat T-cells using a specific AGT1R blocker, candesartan. 
A

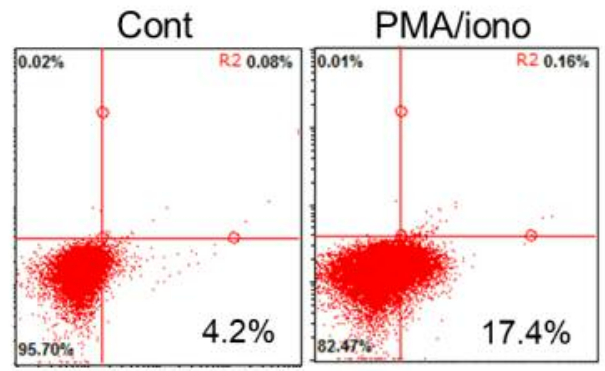

PMA/iono +
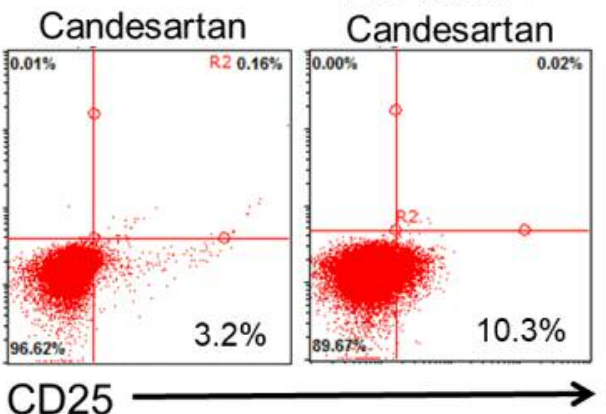

PMA/ionomycin

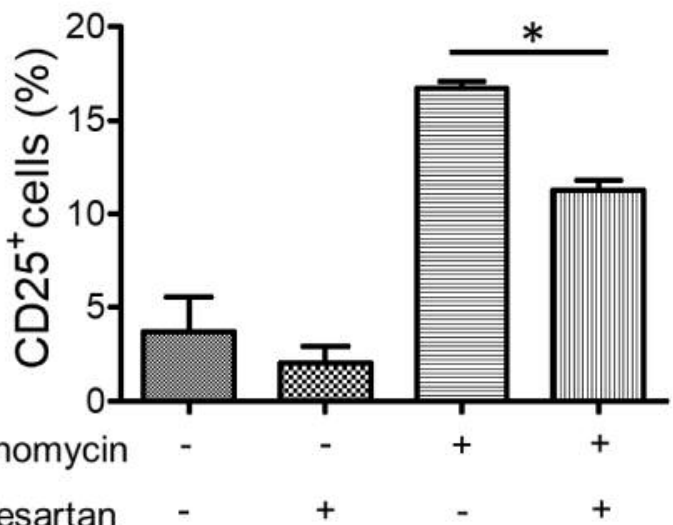

\section{CD25}

C

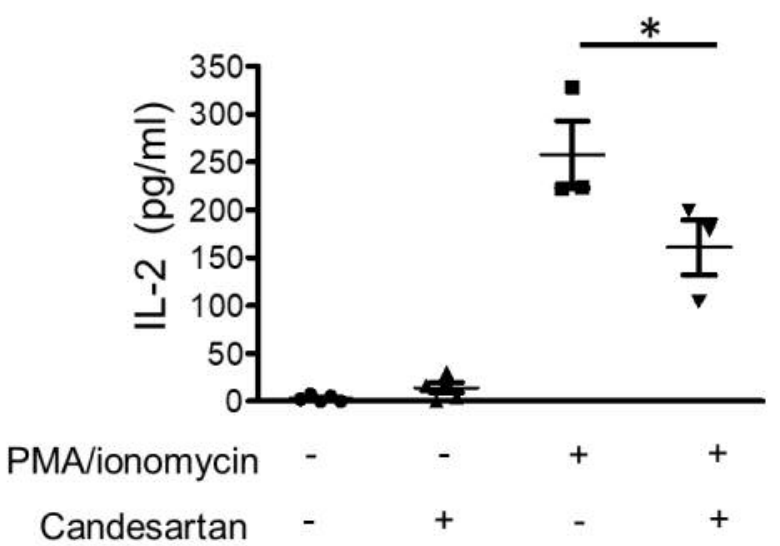

Figure 2. Type 1 angiotensin II receptor inhibitor candesartan reduced T-cell activation. A: Representative dot plot of Jurkat T-cells stained for CD25 expression. Jurkat T-cells were pre-treated with candesartan $1 \mu \mathrm{M}$ and stimulated with $25 \mathrm{ng} / \mathrm{ml}$ of a protein kinase $C$ activator, phorbol myristate acetate (PMA), plus $1 \mu \mathrm{M}$ of a calcium ionophore, ionomycin. After $24 \mathrm{~h}$, cells were harvested and stained with fluorescein isothiocyanate -conjugated antibody to CD25 for flow cytometric analysis, as described in the Materials and Methods. B: The bar graph shows the percentage of CD25+-expressing cells. C: Jurkat T-cells were treated with $1 \mu \mathrm{M}$ candesartan and stimulated with $25 \mathrm{ng} / \mathrm{ml}$ PMA and $1 \mu \mathrm{M}$ ionomycin for 5 h. Culture supernatant was collected and analyzed for interleukin-2 (IL-2) level using an enzyme-linked immunosorbent assay. Data are the mean $\pm S E M$ $(n=3)$. *Significantly different at $p<0.05$.

Our current data reveal that candesartan significantly suppressed the activation of T-cells as shown by CD25 expression and IL-2 production in stimulated T-cells (Figure $2 \mathrm{~B}$ and $\mathrm{C}$ ). For a mechanistic explanation of these effects, we found that blocking AGT1R resulted in significant depletion of ERK phosphorylation and consequently limited the activation of the cells. Our finding is consistent with the fact that not only is the ERK-related mechanism critical for T-cell activation (24), but also that this pathway is important for the growth and survival of $\mathrm{CD}^{+} \mathrm{T}$-cells (25). Regarding IL-2 production, it was shown that ERK regulates the production and secretion of IL-2, as the transfection of Jurkat T-cells with a dominant negative mutant of ERK1 resulted in diminished IL-2 production in stimulated cells (26).

Excessive T-cell activation and IL-2 production are known as key players in several pathological processes. IL-2, predominantly produced by activated T-cells, acts as T-cell growth factor to promote cell proliferation and secretion of pro- 
A

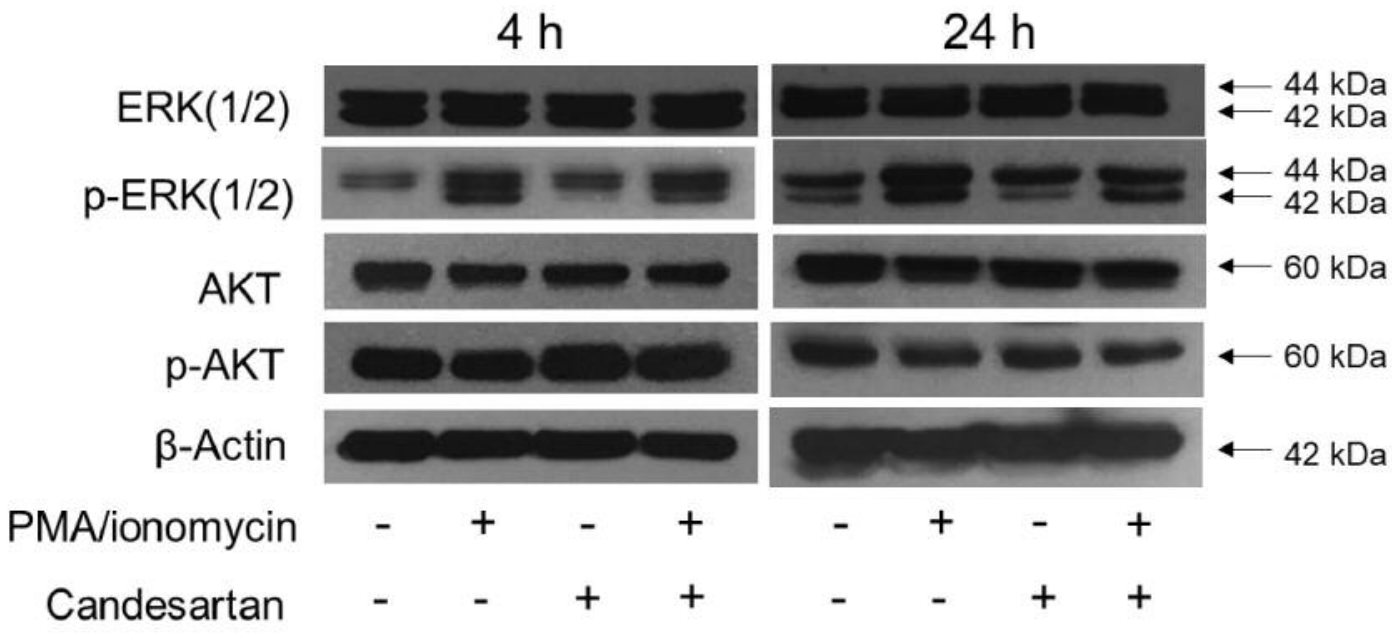

B
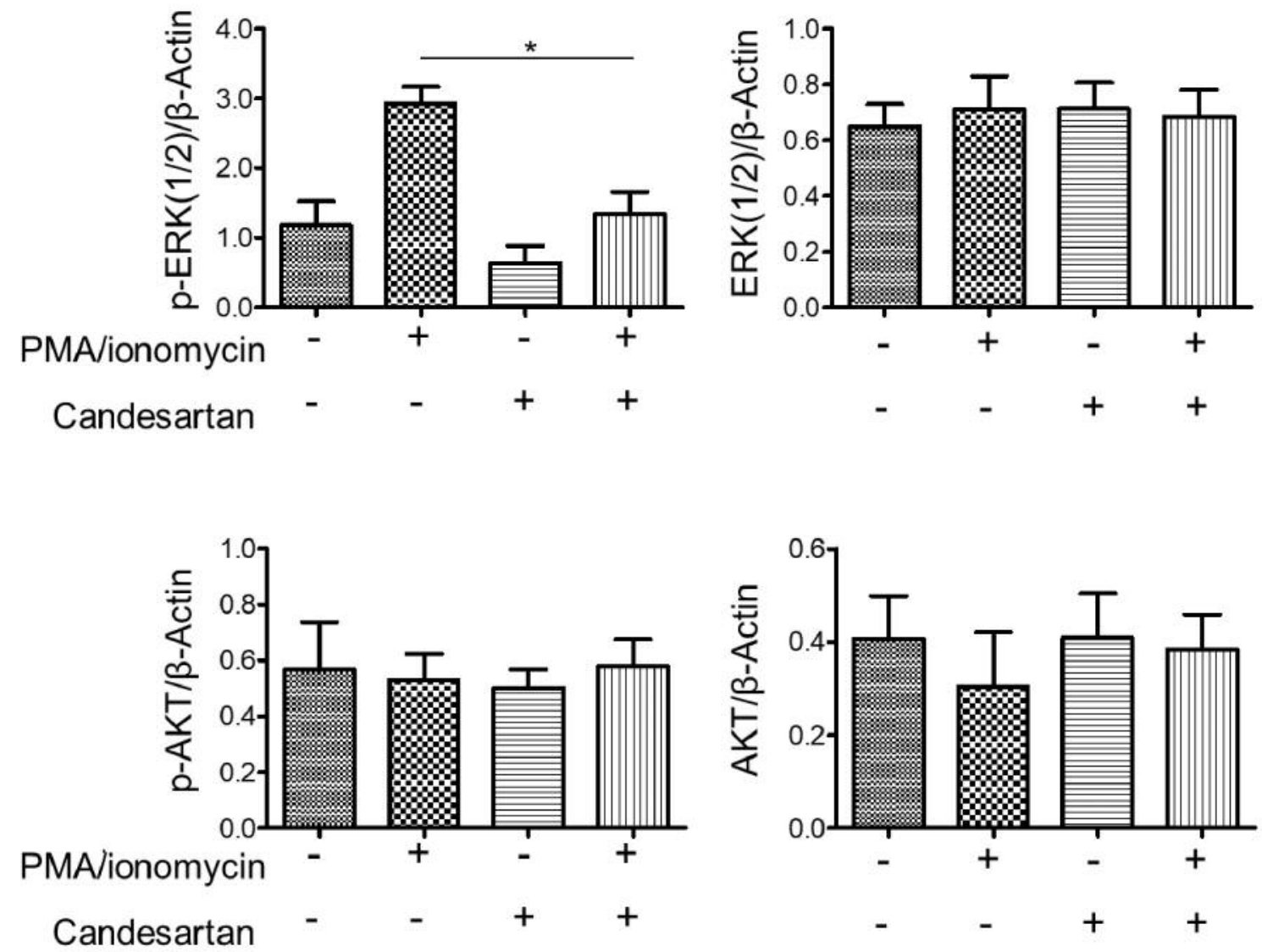

Figure 3. Candesartan inhibited the activation of extracellular signal-regulated kinase (ERK) in Jurkat T-cells. A: Jurkat T-cells were pre-treated with $1 \mu \mathrm{M}$ candesartan and stimulated with $25 \mathrm{ng} / \mathrm{ml}$ of an protein kinase C activator, phorbol myristate acetate (PMA) plus $1 \mu \mathrm{M}$ of a calcium ionophore, ionomycin for 4 and $24 \mathrm{~h}$. Cells were lysed and soluble lysates were analyzed by western blotting for the expression of total ERK(1/2), activated ERK ( $p E R K 1 / 2)$, total $A K T$, and activated AKT ( $p A K T)$. $\beta$-Actin was used to confirm equal protein loading. Data shown are representative of three independent experiments. B: Quantification of target-protein expression normalized with $\beta$-actin relative to the expression of non-treated control. Data are the mean $\pm \operatorname{SEM}(n=3)$. *Significantly different at $p<0.05$. 

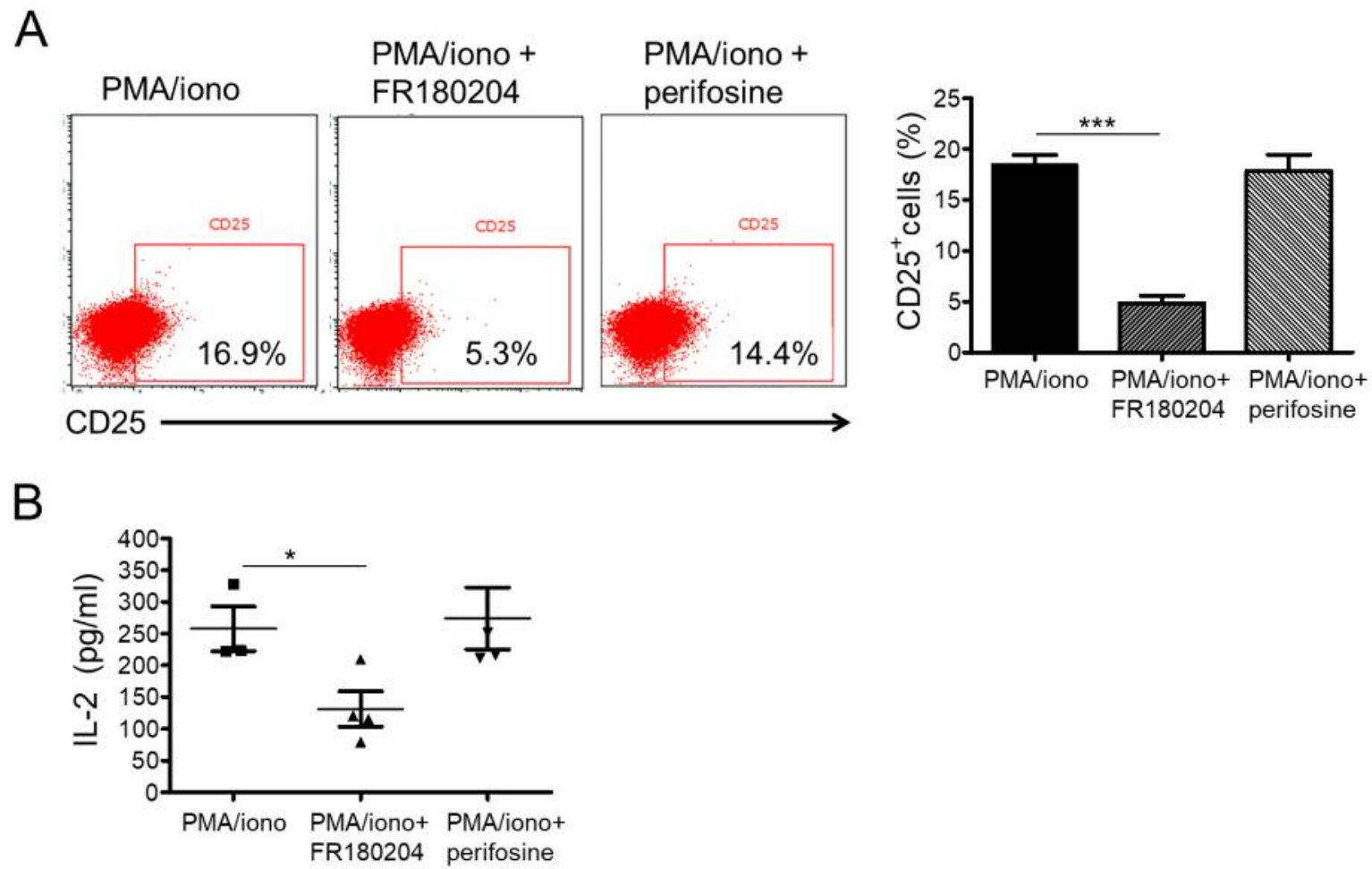

Figure 4. T-Cell activation is dependent on the activation of extracellular signal-regulated kinase (ERK), but not AKT pathway. A: Dot plots represent CD25 expression of Jurkat T-cells. Jurkat T-cells were pre-treated with either $10 \mu M$ of an ERK inhibitor, FR180204 $10 \mu M$ of an AKT inhibitor, perifosine for $15 \mathrm{~min}$. The cells were then stimulated with $25 \mathrm{ng} / \mathrm{ml}$ phorbol myristate acetate (PMA) plus $1 \mu$ M ionomycin. After 24 h, cells were harvested and stained with a fluorescein isothiocyanate-conjugated antibody to CD25 for flow cytometric analysis. The bar graph shows the percentage of cells expressing CD25. Data are the mean \pm SEM (n=3). Significantly different at ${ }^{*} p<0.05$, and ${ }^{* * *} p<0.001$. B: Jurkat T-cells were treated with either $10 \mu M$ FR180204 or $10 \mu \mathrm{M}$ perifosine and stimulated with $25 \mathrm{ng} / \mathrm{ml}$ PMA plus $1 \mu \mathrm{M}$ ionomycin for $5 \mathrm{~h}$. Culture supernatant was collected and analyzed for interleukin-2 (IL-2) levels using an enzyme-linked immunosorbent assay. Data are the mean $\pm S E M(n=3)$. *Significantly different at $p<0.05$.

inflammatory cytokines such as Interferon- $\gamma$, and tumor necrosis factor- $\alpha$ (27). In systemic lupus erythematosus, serum levels of IL-2 and soluble IL-2 receptor are increased in patients with active disease $(28,29)$. In addition, enhanced immune activation by depletion of suppressive regulatory $\mathrm{T}$ cells (Tregs) aggravates aortic aneurysm induced by angiotensin II (30). Thus, adoptive transfer of Tregs to the Treg-deficient mice was found to rescue the animals from increased susceptibility to aortic rupture (30). This is consistent with a study showing that immunosuppression by in vivo expansion of Tregs reduced angiotensin II-induced aortic stiffening (31).

Our study revealed that signaling through AGT1R plays a role in regulation of T-lymphocyte activation and IL-2 secretion. The blockage of AGT1R resulted in the decrease of ERK phosphorylation, highlighting the significant role of ERK in control of T-cell activation and IL-2 production. This knowledge may benefit the better understanding of the role of angiotensin II and its signaling on immune cell function.

\section{Acknowledgements}

This research was funded by Chulalongkorn University, CU-GR_ 60_45_33_10.

\section{References}

1 Yim HE and Yoo KH: Renin-angiotensin system-considerations for hypertension and kidney. Electrolytes Blood Press 6: 42-50, 2008.

2 Hall JE: Control of blood pressure by the renin-angiotensinaldosterone system. Clin Cardiol 14: IV6-21, 1991.

3 Luft FC, Dechend R and Muller DN: Immune mechanisms in angiotensin II-induced target-organ damage. Ann Med 44(Suppl 1): S49-54, 2012.

4 Muller DN, Kvakan H and Luft FC: Immune-related effects in hypertension and target-organ damage. Curr Opin Nephrol Hypertens 20: 113-117, 2011.

5 Ruiz-Ortega M, Ruperez M, Lorenzo O, Esteban V, Blanco J, Mezzano S and Egido J: Angiotensin II regulates the synthesis of proinflammatory cytokines and chemokines in the kidney. Kidney Int Suppl 82: S12-22, 2002. 
6 Zhao H, Li M, Wang L, Su Y, Fang H, Lin J, Mohabeer N and Li D: Angiotensin II induces TSLP via an AT1 receptor/NFkappaB pathway, promoting Th17 differentiation. Cell Physiol Biochem 30: 1383-1397, 2012.

7 Van Stijn CM, Kim J, Barish GD, Tietge UJ and Tangirala RK: Adiponectin expression protects against angiotensin II-mediated inflammation and accelerated atherosclerosis. PLoS One 9: e86404, 2014.

8 Pérez de Lema G, De Wit C, Cohen CD, Nieto E, Molina A, Banas B, Luckow B, Vicente AB, Mampaso F and Schlöndorff $\mathrm{D}$ : Angiotensin inhibition reduces glomerular damage and renal chemokine expression in MRL/lpr Mice. J Pharmacol Exp Ther 307: 275, 2003

9 Di Raimondo D, Tuttolomondo A, Butta C, Miceli S, Licata G and Pinto A: Effects of ACE-inhibitors and angiotensin receptor blockers on inflammation. Curr Pharm Des 18: 4385-4413, 2012.

10 Platten M, Youssef S, Hur EM, Ho PP, Han MH, Lanz TV, Phillips LK, Goldstein MJ, Bhat R, Raine CS, Sobel RA and Steinman L: Blocking angiotensin-converting enzyme induces potent regulatory T-cells and modulates TH1-and TH17mediated autoimmunity. ProcNatl Acad Sci USA 106: 14948149536, 2009

11 Hoch NE, Guzik TJ, Chen W, Deans T, Maalouf SA, Gratze P, Cornelia W and Harrison DG: Regulation of T-cell function by endogenously produced angiotensin II. Am J Physiol Regul Integr Comp Physiol 296: R208-R16, 2009.

12 Tawinwung S, Ninsontia C and Chanvorachote P: Angiotensin II Increases cancer stem cell-like phenotype in lung cancer cells. Anticancer Res 35: 4789-4797, 2015.

13 Arrieta O, Villarreal-Garza C, Vizcaíno G, Pineda B, HernándezPedro N, Guevara-Salazar P, Wegman-Ostrosky T, VillanuevaRodríguez $\mathrm{G}$ and Gamboa-Domínguez A: Association between AT1 and AT2 angiotensin II receptor expression with cell proliferation and angiogenesis in operable breast cancer. Tumour Biol 36: 5627-5634, 2015.

14 DE Azevedo Delou JM, Lopes AG and Capella MA: Effects of angiotensin, vasopressin and aldosterone on proliferation of MCF-7 cells and their sensitivity to doxorubicin. Anticancer Res 34: 1843-1848, 2014.

15 Wang LP, Wang Y, Zhao LM, Li GR and Deng XL: Angiotensin II up-regulates $\mathrm{K}(\mathrm{Ca}) 3.1$ channels and stimulates cell proliferation in rat cardiac fibroblasts. Biochem Pharmacol 85: 1486-1494, 2013.

16 Agarwal D, Dange RB, Raizada MK and Francis J: Angiotensin II causes imbalance between pro-and anti-inflammatory cytokines by modulating GSK-3beta in neuronal culture. Br J Pharmacol 169: 860-874, 2013.

17 Guo F, Chen XL, Wang F, Liang X, Sun YX and Wang YJ: Role of angiotensin II type 1 receptor in angiotensin II-induced cytokine production in macrophages. J Interferon Cytokine Res 31: 351-361, 2011.

18 Hayashi M, Takeshita K, Uchida Y, Yamamoto K, Kikuchi R, Nakayama T, Nomura E, Cheng XW, Matsushita T, Nakamura S and Murohara T: Angiotensin II receptor blocker ameliorates stress-induced adipose tissue inflammation and insulin resistance. PLoS One 9: e116163, 2014.
19 Jurewicz M, McDermott DH, Sechler JM, Tinckam K, Takakura A, Carpenter CB, Milford E and Abdi R: Human T-and natural killer cells possess a functional renin-angiotensin system: further mechanisms of angiotensin II-induced inflammation. J Am Soc Nephrol 18: 1093-1102, 2007.

20 Nataraj C, Oliverio MI, Mannon RB, Mannon PJ, Audoly LP, Amuchastegui CS, Ruiz P, Smithies $\mathrm{O}$ and Coffman TM: Angiotensin II regulates cellular immune responses through a calcineurin-dependent pathway. J Clin Invest 104: 1693-1701, 1999.

21 Guzik TJ, Hoch NE, Brown KA, McCann LA, Rahman A, Dikalov S, Goronzy J, Weyand C and Harrison DG: Role of the $\mathrm{T}$-cell in the genesis of angiotensin II induced hypertension and vascular dysfunction. J Exp Med 204: 2449-2460, 2007.

22 Popa CD and van Riel PL: The use of captopril in rheumatoid arthritis: Combining treatment targets! Can J Cardiol 29: 639.e13, 2013.

23 Silveira KD, Coelho FM, Vieira AT, Barroso LC, Queiroz-Junior CM, Costa VV, Sousa LF, Oliveira ML, Bader M, Silva TA, Santos RA, Silva AC and Teixeira MM: Mechanisms of the antiinflammatory actions of the angiotensin type 1 receptor antagonist losartan in experimental models of arthritis. Peptides 46: 53-63, 2013.

24 Koike T, Yamagishi H, Hatanaka Y, Fukushima A, Chang JW, Xia Y, Fields M, Chandler P and Iwashima M: A novel ERKdependent signaling process that regulates interleukin-2 expression in a late phase of T-cell activation. J Biol Chem 278: 15685-45692, 2003.

25 D'Souza WN, Chang CF, Fischer AM, Li M and Hedrick SM: The Erk2 MAPK regulates CD8 T cell proliferation and survival. J Immunol 181: 7617-7629, 2008.

$26 \mathrm{Li}$ YQ, Hii CST, Der CJ and Ferrante A: Direct evidence that ERK regulates the production/secretion of interleukin-2 in PHA/PMAstimulated T-lymphocytes. Immunology 96: 524-528, 1999.

27 Ye C, Brand D and Zheng SG: Targeting IL-2: an unexpected effect in treating immunological diseases. Signal Transduc Target Ther 3: 2, 2018.

28 Sedighi S, Aghaei M, Musavi S and Nomali M: Relationship between serum level of interleukin-2 in patients with systemic lupus erythematosus and disease activity in comparison with control group. J Clin Diagn Res 8: MC16-8, 2014.

29 El-Shafey EM, El-Nagar GF, El-Bendary AS, Sabry AA and Selim AG: Serum soluble interleukin-2 receptor alpha in systemic lupus erythematosus. Iran J Kidney Dis 2: 80-85, 2008.

30 Ait-Oufella H, Wang Y, Herbin O, Bourcier S, Potteaux S, Joffre J, Loyer X, Ponnuswamy P, Esposito B, Dalloz M, Laurans L, Tedgui A and Mallat Z: Natural regulatory T-cells limit angiotensin II-induced aneurysm formation and rupture in mice. Arterioscler Thromb Vasc Biol 33: 2374-2379, 2013.

31 Majeed B and Tawinwung S: Interleukin-2/anti-interleukin-2 immune complex expands regulatory $\mathrm{T}$-cells and reduces angiotensin II-induced aortic stiffening. Int J Hypertens 2014: $126365,2014$. 